\title{
Money Laundering: An Overview
}

\author{
Deepa Joshi ${ }^{1}$, Ashutosh Vyas ${ }^{2}$, Ms. Megha Joshi ${ }^{3}$
}

${ }^{1}$ Associate Professor, Shri Vaishnav Institute of Management, Indore, India

${ }^{2}$ Assistant Professor, Shri Vaishnav Institute of Management, Indore, India

${ }^{3}$ Research Scholar, Shri Vaishnav Institute of Management, Indore, India

\begin{abstract}
Money laundering is generally regarded as the practice of engaging in financial transactions to conceal the identity, source, and/or destination of illegally gained money by which the proceeds of crime are converted into assets which appear to have a legitimate origin. In other words, Money Laundering refers to the conversion or "Laundering" of money which is illegally obtained, so as to make it appear to originate from a legitimate source. The recent activity in money laundering in India is through political parties' corporate companies and share market. Bank fraud is a serious financial crime that involves the unlawful obtainment of funds from a bank or other financial institution. Money is the root cause of many evils like corruption, black marketing, smuggling, drug trafficking, tax evasion, and the buck does not stop here. While carrying out the Know your Client (KYC) norms, special care has to be exercised to ensure that the contracts are not anonymous or under fictitious names. Money is the prime reason for engaging in almost any type of criminal activity .Money laundering is the method by which criminals disguise the illegal origins of their wealth.
\end{abstract}

Key-Words: Money Laundering, Anti- Money Laundering (AML), Know Your Customer(KYC), Financial Action Task Force ( FATF)

\section{GEL Classification Code: E49; E50; P44}

\section{INTRODUCTION}

Money laundering is generally regarded as the practice of engaging in financial transactions to conceal the identity, source, and/or destination of illegally gained money by which the proceeds of crime are converted into assets which appear to have a legitimate origin. In other words, Money Laundering refers to the conversion or "Laundering" of money which is illegally obtained, so as to make it appear to originate from a legitimate source. Money Laundering is being employed by launderers worldwide to conceal criminal activity associated with it such as drug / arms trafficking, terrorism and extortion The money which is legally obtained is known as "CLEAN MONEY", and the money which is illegally obtained is known as "DIRTY MONEY".

Generally, Money Launderers tend to seek out areas in which there is a low risk of detection due to weak or ineffective anti-money laundering programmes. Because the objective of Money Laundering is to get the illegal funds back to the individual who generated them, launderers usually prefer to move funds through areas with stable 
financial systems. Money Laundering is a threat to the good functioning of a financial system. However, it can also be the Achilles heel for criminal activities.

\section{Stages of Money Laundering}

There are three independent steps or stages in Money Laundering as shown below:

- Placement: "Placement" refers to the physical disposal of bulk cash proceeds derived from illegal activity.

- Layering: "Layering" refers to the separation of illicit proceeds from their source by creating complex layers of financial transactions. Layering conceals the audit trail and provides anonymity.

- Integration: "Integration" refers to the reinjection of the laundered proceeds back into the economy in such a way that they re-enter the financial system as normal business funds.

\section{FINANCIAL ACTION TASK FORCE (FATF)}

Financial Action Task Force (FATF) an intergovernmental body was formed in 1989 by the G7-summit at Paris, with the purpose to develop and promote the policies, both at national and international levels, to combat money laundering and terrorist financing. It is a "policy-making body" that works to generate the necessary political will to bring about legislative and regulatory reforms in these areas. The membership has now steadily grown to encompass 33 nations, most of them from the Organisation for Economic Co-operation and Development (OECD). Over the years, the FATF has developed about 40 recommendations to guide states in their attempts to strengthen their financial systems that have come to be regarded as world standards. Since 2001, the FATF has also expanded its activities to include the financing of terrorism and as a result, there are now nine special recommendations. The recommendations set minimum standards for action for countries to implement the detail according to their particular circumstances and constitutional frameworks.

\section{Who can be a Member of FATF?}

A Country can be a member of FATF if it is:

- A strategically important country which is a full and active member of FATF-style Regional Body.

- With a letter from an appropriate Minister or person of equivalent political level making a political commitment to implement the FATF recommendations within a reasonable time frame and to undergo the mutual evaluation process; and

- Effectively criminalize money laundering and terrorist financing;

- Make it mandatory for financial institutions to identify their customers, to keep customer records and to report suspicious transactions; and

- Establish an effective FIU (Financial Intelligence Unit), so that the country will be assessed fully or largely compliant with recommendations

The Prevention of Money-Laundering Act, 2002 came into effect on 1 July 2005. Section 3 of the Act makes the offense of money-laundering cover those persons or entities who directly or indirectly attempt to indulge or knowingly assist or knowingly are party or are actually involved in any process or activity connected with the proceeds of crime and projecting it as untainted property, such person or entity shall be guilty of offense of money-laundering. Section 4 of the Act prescribes punishment for money-laundering with rigorous imprisonment for a term which shall not be less than three years but which may extend to 
seven years and shall also be liable to fine which may extend to five lakh rupees and for the offences mentioned [elsewhere] the punishment shall be up to ten years.

Section 12 (1) prescribes the obligations on banks, financial institutions and intermediaries (a) to maintain records detailing the nature and value of transactions which may be prescribed, whether such transactions comprise of a single transaction or a series of transactions integrally connected to each other, and where such series of transactions take place within a month; (b) to furnish information of transactions referred to in clause (a) to the Director within such time as may be prescribed and $t$ records of the identity of all its clients. Section 12 (2) prescribes that the records referred to in sub-section (1) as mentioned above, must be maintained for ten years after the transactions finished.

The recent activity in money laundering in India is through political parties corporate companies and share market.Bank fraud is a serious financial crime that involves the unlawful obtainment of funds from a bank or other financial institution. Bank fraud cases are usually distinguished from outright bank robbery as they rely on the use of deception and confidence tricks rather than the threat or use of violence. Bank fraud cases come in many different forms, including several types of check fraud, identity theft, embezzlement, and document fraud.

Anti money laundering and Economic Development: The negative economic effects of money laundering on economic development are difficult to quantify, yet it is clear that such activity damages the financial-sector institutions that are critical to economic growth, reduces productivity in the economy's real sector by diverting resources and encouraging crime and corruption, which slow economic growth, and can distort the economy's external sectorinternational trade and capital flows - to the detriment of long-term economic development. Developing countries' strategies to establish offshore financial centers (OFCs) as vehicles for economic development are also impaired by significant money-laundering activity through OFC channels. Effective anti-money-laundering policies, on the other hand, reinforce a variety of other good-governance policies that help sustain economic development, particularly through the strengthening of the financial sector.

\section{Insurance Sector:}

The most common form of money laundering that insurance institutions will encounter takes the form of a proposal to enter into single premium contract, lump sum top-ups to an existing life contract. These contracts in themselves may be merely one part of a sophisticated web of complex transactions, which will often have their origins elsewhere in the financial services sector. Money laundering is confused to the fraudulent practices prevalent in industry like fraudulent claims. It is also thought to be relatable to foreign exchange transactions, and both of these are some of the misconceptions about money laundering. They may be merely one of the stages of laundering money.

\section{Banking Sector:}

Across the world, banks have become a major target of Money Laundering operations and financial crime because they provide a variety of services and instruments that can be used to conceal the source of money. What are the implications of Money Laundering for banks? Launderers employ currency deposits, fake businesses and cash being generated through legitimate businesses. Across the world, banks and financial institutions are liable for prosecution if their employees become involved in Money Laundering activities. At the same time, norms for record keeping, reporting, account opening and transaction monitoring are being introduced by central banks across the globe for checking the incidence of Money Laundering. Employees of banks are also being trained 
to recognize suspicious transactions. The dilemma of the banker in the context of Money Laundering is to sift the transactions representing legitimate business and banking activity from the irregular / suspicious transactions.

Banks were advised to follow certain customer identification procedure for opening of accounts and monitoring transactions of a suspicious nature for the purpose of reporting it to appropriate authority. These 'Know Your Customer' guidelines have been revisited in the context of the Recommendations made by the Financial Action Task Force (FATF) on Anti Money Laundering (AML) standards and on Combating Financing of Terrorism (CFT). These standards have become the international benchmark for framing Anti Money Laundering and combating financing of terrorism policies by the regulatory authorities. Compliance with these standards both by the banks/financial institutions and the country have become necessary for international financial relationships. Detailed guidelines based on the Recommendations of the Financial Action Task Force and the paper issued on Customer Due Diligence(CDD) for banks by the Basel Committee on Banking Supervision, with indicative suggestions wherever considered necessary are enclosed. Banks are advised to ensure that a proper policy framework on 'Know Your Customer' and Anti-Money Laundering measures is formulated and put in place with the approval of the Board within three months of the date of this circular. It may also be ensured that banks are fully compliant with the provisions of this circular before December 31, 2005. This facility is being provided absolutely FREE OF COST to the investors. To begin with, investors investing Rs.50,000 or more will have to comply with KYC effective from 1st February, 2008.

KYC controls typically include below details:

- Collection and analysis of basic identity information (CIP)

- Name matching against lists of known parties

- Determination of the customer's risk in terms of propensity to commit money laundering or identity theft

- Creation of an expectation of a customer's transactional behavior

- Monitoring of a customer's transactions against their expected behavior and recorded profile as well as that of the customer's peers.

\section{LITERATURE REVIEW}

Kini, Satish M,Fischer, Eric R,Kales, Andrew B,Kerr, Richard studied on the provisions of the new Bank Secrecy Act (BSA)/ Anti-Money Laundering Examination Manual and its implications for banks and other financial institutions. The BSA Manual is designed as a reference manual for both examiners and banks. The purpose of the manual, as noted in its introduction, is to "ensure consistency" in the application of BSA requirements among the federal bank regulatory agencies. The BSA Manual also serves to inform banks regarding compliance program requirements and examiner expectations. In the introduction, the BSA Manual makes clear that banks must adopt a risk-based approach to anti-money laundering compliance.

Longfellow, Tom provides advice for meeting U.S. federal anti-money laundering regulations. Money laundering has become a significant concern since the terrorist attacks of September 11, 2001 on the United States, as U.S. federal officials have become wary of organizations that launder money to finance terrorism. A series of suspicious activity indicators for banking customers are also provided, including checks on 
customer behavior, the opening of multiple bank accounts, and frequent account activity. Morales, Rafael. A focuses on a court ruling by the Philippines' Supreme Court in a case, which effectively restrained the initiatives of the Anti-Money Laundering Council (AMLC) to combat money laundering activities in the country. As part of Section 11 of the Anti-Money Laundering Act, the AMLC is authorized to inquire, upon order of any competent court, into any financial transactions that violates the Act. The Supreme Court ruling cited that Section 10 of the Act explicitly allows ex parte applications for a court order to freeze monetary instruments, but similar ex parte language is not found in the case of Section 11.

Accountants present guidance issued by the Consultative Committee of Accountancy Bodies for accountants in fulfilling the requirements of the anti-money laundering sections of Great Britain's Proceeds of Crime Act 2002 and the Money Laundering Regulations 2003. These legislations introduce major changes to accountants' responsibilities and potential criminal liability for all accountants working in Great Britain. Money laundering now includes possessing, or in any way dealing with, or concealing, the proceeds of the crime. For the purposes of the guidance, it also involves similar activities relating to terrorist funds, which include funds that are likely to be used for terrorism, as well as the proceeds of terrorism. Accountants working in practice or other relevant businesses must report knowledge or suspicions of money laundering to the National Criminal Intelligence Service. Businesses, principals and employees face significant criminal penalties where they breach the requirements of the new legislation. Hülsse, Rainer," Kerwer, Dieter said as organizations have come under the increasing influence of global rules of all sorts, organization scholars have started studying the dynamics of global regulation. The purpose of this article is to identify and evaluate the contribution to this interdisciplinary field by the 'Stockholm Centre for Organisational Research'. The latter's key proposition is that while global regulation often consists of voluntary best practice rules it can nevertheless become highly influential under certain conditions. We assess how innovative this approach is using as a benchmark the state of the art in another field of relevance to the study of global regulation, i.e. 'International Relations'. Our discussion is primarily theoretical but we draw on the case of global anti-money laundering regulation to illustrate our arguments and for inspirations of how to further elaborate the approach.

Gnutzmann, Hinnerk,McCarthy, Killian J,Unger, Brigitte explained the incidence of money laundering, and the zeal with which international anti-money laundering (AML) policy is pursued, varies significantly from country to country, region to region. There are, however, quite substantial social costs associated with a policy of toleration, and this begs the question as to why such a variance should exist. In this paper we claim that, due to the globalisation of crime, if a single country should break the "chain of accountability", then it will provide a safe haven for criminals and attract the total financial proceeds of crime. Because smaller economies are best able to insulate themselves from the costs of crime, we argue that smaller countries bear only a tiny share of the total costs relative to the potential benefits of investment that money laundering offers, and so have a higher incentive to tolerate the practice compared to their larger neighbours. As such, we claim that the existence of a money laundering market is due to a policy of AML 'defection', and that the degree of 'defection' depends largely on the size of the country. We present a simple model of policy competition which formalises this intuition, and conclude by exploring a number of policy recommendations which flow from this. [Copyright \&y\& Elsevier] 


\section{Rationale OF THE STUdY}

Money is the root cause of many evils like corruption, black marketing, smuggling, drug trafficking, tax evasion, and the buck does not stop here .People are crazy for money. Majority is here to become rich and money has become the basic goal of education. The more developed the nation, the more the standard of living of the people. People want more money to cater to their needs and at a point of time they don't hesitate to have money from any source (black or white who cares). This is the available soft corner where the concept of money laundering enters and prospers. Though academically it could be discussed that money-laundering may prove useful in certain context, in light of the harmful effects of money-laundering posed above no one would argue against the anti-money-laundering laws. There are various motivations to have an AML mechanism in place. To begin with, at the most basic, the rationale is to support the adage that "crimes don't pay". Firstly, there is the moral dimension: crime should not pay. It is simply not acceptable to society that a person who does wrong should benefit as a result. Apart from the aforesaid dimension, it is intended to deprive the criminal organization of their "financial lifeblood." Moreover, if it is shown that crime does not pay would act as a sufficient deterrent, as few theorists suggest for cost-benefit analysis, especially in economic crimes like money-laundering. Further, there is another theory that if criminals can be prevented from profiting from their offences, they will not be able to re-invest money in those various ways and hence will be hampered from committing further offences. We live in a globalized world as a community and have international relations at stake. There are pressures from parent organizations to which one has acceded to as well as pressures from the developed countries for compliance to tough anti-moneylaundering regimes. The compliance results in better international status of the country. Antimoney laundering law is necessary because money laundering tends to corrupt even the most professional players in the market. Now a money-launderer can be a white collar businessman doing the business legitimately. Money laundering promotes corruption and bribery in every sector, specifically the banking and insurance sector.

\section{OBJectives}

To study the role of Anti Money Laundering on Indian financial Sector.

\section{Research Methodology}

The research methodology includes a combination of literature review and secondary data. The purpose was to use theory as a base for the research and support when doing analysis and making conclusions. The whole study is done from a management perspective.

Data collection: Information mainly from the Internet, journals and magazines, books, earlier research works and so on.

Research design: This study is an analytical and descriptive in nature.

\section{FINDINGS}

The major findings of this research study were as follows:

- While carrying out the Know your Client (KYC) norms, special care has to be exercised to ensure that the contracts are not anonymous or under fictitious names.

- KYC process is initially to be done as per the extent guidelines. Any changes in the customer's recorded profile that comes to the notice of the insurer and which is inconsistent with the normal and expected activity of the customer should attract the attention of the 
insurer for further ongoing KYC processes and action as considered necessary.

- Insurers should devise procedure to ensure that proposals for contracts with high risk customers are concluded after approval of senior management officials . It is however, emphasized that proposals of Politically Exposed Persons(PEP's) in particular requires approval of senior management, not below Head(underwriting) / Chief Risk Officer level.

- It is advised that special attention is paid to all complex unusually large transactions and all unusual patterns which have no apparent economic or visible lawful purpose and transactions.

- It is further advised that the background including all documents / office records memorandums pertaining to such transactions as far as possible, be examined by the Principal Compliance Officer for recording his findings. These records are required to be preserved for ten years.

- Principal Compliance Officer for AML guidelines should be at senior level and preferably not below the Head / Chief Risk Officer level and should be able to act independently and report to senior management.

- Principle compliance officer for AML guideline and staff assisting him in execution of AML guidelines should have timely access to customer identification data, other KYC information and records.

- Directors, officers and employees shall be prohibited from disclosing the fact that a Suspicious Transactions Report or related information of a policyholder / prospect is being reported to the FIU-IND.

Various levels of Anti-Money Laundering

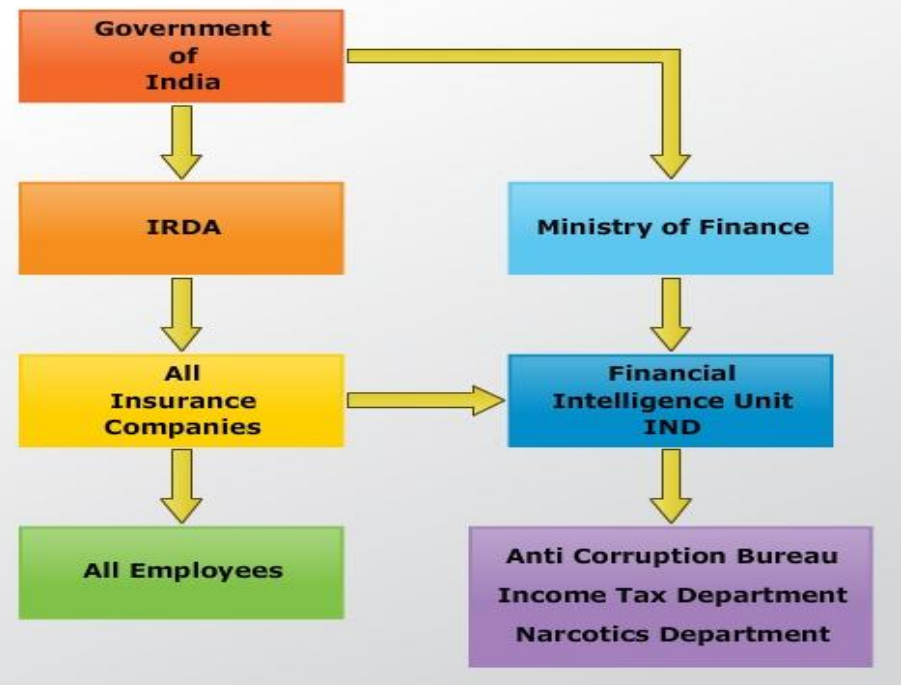

\section{CONCLUSION}

Money is the prime reason for engaging in almost any type of criminal activity .Money laundering is the method by which criminals disguise the illegal origins of their wealth and protect their asset bases, By doing so they can avoid the suspicion of law enforcement agencies. Criminals are now taking advantage of the globalization of the 
world economy by transferring funds quickly across international borders.

Impact of Dirty Money: There are basically two impact of dirty money

- It causes criminal offence.

- It causes reputation damage to the financial institutions alleged of dealing with illicit money.

- It also increases crime and corruption which adversely affects economic growth.

- It reduces the productivity of financial institutions by diverting resources.

- It has an adverse effect on economy and affects the legal system. It is moving illegally, the acquired cash through financial system and gives virtual appearance of legally acquired cash.

It leads to rise in Inflation Rates and increase Criminal Rate

- Flow of dirty money in the system increases purchasing power of people and leads to an increase in demand for goods and services in the market.

- The dirty money enters in the financial system it is difficult to trace and curb inflation.

- Availability of dirty money from different sources increases the strength of criminals and gives them a free hand to spend on illegal activities.

Combating with Dirty Money: Finally we conclude that through AML we are able to stop the entry of dirty money in system.AML prevents our whole economy and society from dirty money. AML combating with dirty money on the points (a) KYC norms and due diligence processes, (b) Regulatory compliance, (c) AML training for employees and agents, (d) Close cooperation with IRDA, Financial Intelligence Unit-India and Lawenforcement agencies, (e) Suspicious activity reporting, (f) Monitoring and Surveillance.

\section{REFERENCES}

\section{Bibliography}

International Review of Law \& Economics; Sep2010, Vol. 30 Issue 3, p244-252, 9p

Accountancy; Apr2004, Vol. 133 Issue 1328, p112-124, 13p

International Financial Law Review; May2009, Vol. 28 Issue 5, p42-42, 1p

Banking Law Journal; Oct2005, Vol. 122 Issue 9, p940-952, 13p

Organization; Sep2007, Vol. 14 Issue 5, p625-642, 18p

Organization; Sep2007, Vol. 14 Issue 5, p625-642, 18p

Journal of Financial Planning; Sep2006 Supplement, p15-15, 1p

V.K.Bhalla,"International Finance Management",22nd Edition, Anmol Publications, 2001.

Ian.H.Giddy, "Global Financial Markets”, Delhi, AITBS Publications, 1997.

O.S.Gupta, "Life Insurance", Special Reference to L.I.C.

Vasant Joshi and Vinay Joshi, "Managing Indian Banks”, Response Books.

\section{Webliography}

www.google.com

www.wikipedia.com

www.ebsco.com

www.ebooklibs.com

www.encylopedia.com

www.scribd.com

www.researchpapers.com 